\title{
Synergy and/or Antagonism in a Cover Crop Sequence: Rotational Effects on Rye in the Midwest
}

\author{
D. Esther Shekinah ${ }^{1} \&$ James K. Stute ${ }^{2}$ \\ ${ }^{1}$ Research Scientist, Michael Fields Agricultural Institute, East Troy, Wisconsin 53120, USA \\ ${ }^{2}$ Research Director, Michael Fields Agricultural Institute, East Troy, Wisconsin 53120, USA \\ Correspondence: James K. Stute, Michael Fields Agricultural Institute, East Troy, Wisconsin 53120, USA. \\ E-mail: jstute@michaelfields.org
}

Received: February 21, $2019 \quad$ Accepted: March 15, $2019 \quad$ Online Published: April 10, 2019
$\begin{aligned} & \text { doi:10.5539/sar.v8n2p90 } \\ & \text { URL: https://doi.org/10.5539/sar.v8n2p90 }\end{aligned}$

\begin{abstract}
Cover cropping reduces soil erosion mainly by providing cover when the soil is left barren after a short season crop. It also improves nutrient cycling and prevents the loss of $\mathrm{NO}_{3}-\mathrm{N}$ by leaching especially during late fall and early spring season. When CCs are grown in a sequence, they are able to harvest both the benefits mentioned above and provide ecological services. However, there may be synergistic or antagonistic effects in action between CCs just as is the case of CC allelopathy in weed control. Field experiments were conducted over two cropping seasons (2016-16 and 2016-17) at Michael Fields Agricultural Institute, Wisconsin on a forest derived Fox silt loam (Fine-loamy, mixed, mesic Typic Hapludalfs) under organic certification to determine the effect of sequential planting of CCs on Above Ground Biomass (AGB) yield, $\mathrm{N}$ and $\mathrm{C}$ addition and to determine the synergistic or antagonistic effect of the species grown in a sequence on each other. Ten different species of CCs were planted immediately after crop harvest in early August followed by winter rye in a sequence, after roll-crimping of the first cover. The cropping sequences significantly affected the cover crop yield and related parameters. Radish - winter rye sequence was the best performing one in both years of study with regard to the AGB yield (13.96 and $14.87 \mathrm{Mg} \mathrm{ha}^{-1}$ respectively), and large amounts of $\mathrm{N}$ and $\mathrm{C}$ added to the soil. Phacelia winter rye followed close, with the sequence recording on par yields in 2015-16 (13.28 $\left.\mathrm{Mg} \mathrm{ha}^{-1}\right)$. Winter rye performed better following a dicot compared to monocot; non-legume compared to a legume. The CC sequences also exhibited synergism and antagonism. The yield of winter rye was boosted when the biomass yield of the forage radish it followed increased, which we consider as synergy: while the yield of winter rye reduced whenever the yield of oat, barley or beseem clover it followed increased, which we consider as an antagonistic effect. The other CCs performed moderately and were greatly a reflection of the prevailing weather conditions. More research along this line is recommended to generate research based information on synergy and antagonism in $\mathrm{CC}$ sequence.
\end{abstract}

Keywords: cover crop, sequence, synergy, antagonism, winter rye, radish, oat, barley, berseem clover, biomass

Abbreviations: AGB, aboveground biomass; CC, cover crop; CE, carbon dioxide equivalent; SOC, soil organic carbon; SOM, soil organic matter

\section{Introduction}

Cover cropping compared to bare fallow can maintain or increase SOM and also increase C and $\mathrm{N}$ in the soil by increasing residue return. It also improves soil physical properties of infiltration, bulk density and reduces soil that is displaced by wind and water erosion. Though reduction in soil erosion is the primary benefit of cover cropping, other ecological benefits include enhanced nutrient cycling and biological $\mathrm{N}_{2}$ fixation, improved weed control, and increased crop yields (Altieri, 1999; Reddy et al., 2003; Teasdale et al., 2007; Wortman et al., 2012a). These benefits vary based on the choice of CC, either legume or cereal, grown either solely or in polyculture. Legumes increase $\mathrm{N}$ through biological fixation, while cereals tend to increase $\mathrm{C}$ by adding large amounts of biomass (Wortman et al., 2012b). Most farmers choose to grow single species solely to enhance the ease of planting operations (Mirsky et al., 2009).

Growing corn (Zea mays L.) or soybean [Glycine max (L.) Merr] in rotation leaves the soil barren for 5 to 6 months in a year. With little soil cover this can result in soil erosion, nitrate leaching, decreased soil microbial 
activity, decreased accumulation of SOC, and increased weed density (Appelgate et al., 2017; Shekinah \& Stute, 2018). Most of these losses occur because of a lack of actively growing plants in the late fall or early spring.

Various CCs like barley (Hordeum vulgare L.), oat (Avena sativa L.), buckwheat (Fagopyrum esculentum Moench.), berseem clover (Trifolium alexandrinum L.), radish (Raphanus sativus L.), sunn hemp (Crotalaria juncea L.), winter pea [Pisum sativum subsp. arvense (L.) Asch], phacelia (Phacelia tanacetifolia Benth.) and chickling vetch (Lathyrus sativus L.) are options for planting after harvest of a short season crop such a winter wheat (Triticum aestivum L.) which could expand the rotation. Once these winterkill or are terminated, planting a sequential winter CC could provide biomass in the late fall/ early spring. Winter rye (Secale cereale L.) is the most often chosen CC for the ability to survive extremely harsh winters and germinate and produce large amounts of biomass at low temperatures (Snapp et al., 2005; Singer, 2008). Winter growth allows CCs to utilize residual soil $\mathrm{N}$ that may otherwise leach into groundwater after crop harvest in the fall, and depending on the species, can sequester atmospheric $\mathrm{C}$ and/or $\mathrm{N}$, thereby reducing the amount of fertilizer $\mathrm{N}$ required for summer crops (Kuo et al., 1997a; 1997b). Also, the winter CC could utilize the ecosystem services rendered by the previous $\mathrm{CC}$ in rotation to enhance its growth and to provide additional agronomic services to improve productivity of the ensuing cash crop. However, maximizing the agronomic benefits associated with CCs will depend on the appropriate species choice and residue management (Ashford \& Reeves, 2003; Wortman et al., 2012a).

Sequential cover cropping, besides providing soil cover for a longer period could also increase the amount of biomass produced, and consequently, the associated benefits such as added $\mathrm{C}$ and $\mathrm{N}$. When plant diversity was increased, nutrient retention was greater and overall plant biomass productivity was 2 to 10 -fold greater in high diversity ecosystems compared to monocultures (Tilman et al. (1997) as reviewed in Appelgate et al., 2017). There may also be synergistic or antagonistic effects of one species on the other. Allelopathic effects from Brassicaceae CCs have been studied and are effective in the greenhouse (Haramoto \& Gallandt, 2004), but show little evidence for being effective in the field (Haramoto \& Gallandt, 2005). Teasdale (1996) reported that CC allelopathic effects are inconsistent and often difficult to document in field studies. These are reviewed by Appelgate et al. (2017). The antagonistic nature of winter rye towards other species, most notably corn (as compared to soybean) has been well documented (Moore et al., 2014; Johnson et al., 1998; Raimbault et al., 1990). Our preliminary research also indicates its antagonistic effect on sorghum- sudan [Sorghum bicolor (L.) Moench] hybrid when grown in sequence, but not on buckwheat (Stute, unpublished). Is it possible then that other CCs also show such antagonism on cover crops that follow? Or are there synergistic or yield enhancing effects when species are grown in sequence?

The growth characteristics and benefits of individual species have been well documented. Holes et al. (2017) have reviewed the literature and report: forage radish planted as a fall CC can substantially reduce weed biomass; cowpea [Vigna unguiculata (L.) Walp.] has been shown to be highly productive and capable of fixing N; buckwheat can suppress weed communities like pig weeds (Amaranthus spp.), foxtails (Setaria spp.) and velvetleaf (Abutilon theophrasti Medik.); winter rye can scavenge soil $\mathrm{N}$ that could be otherwise lost in its biomass and supply it to the following crop. Buckwheat can be a productive summer CC producing as much at 7 $\mathrm{Mg} \mathrm{ha}{ }^{-1}$. Our interest was therefore to see if the species-specific benefits gets translated additively or synergistically when grown in a sequence, utilizing the period between the harvest of the short summer crop and the planting of the cash crop in spring. Increasing the temporal plant diversity within the fallow period using CCs can increase ecosystem services (Finney et al., 2016). Also, CCs exhibiting different phenology, architecture and physiology can exhibit maximum biomass production, not only when grown as a mixture but also when grown in a sequence.

This experiment involved the evaluation of ten potential CCs followed by winter rye to obtain research-based information on sequential cover cropping. Our objectives were to: (1) evaluate the effectiveness of sequential cover cropping on AGB production, $\mathrm{C}$ and $\mathrm{N}$ content as well as the $\mathrm{C}: \mathrm{N}$ ratio; and (2) determine if there is synergy or antagonism between species grown sequentially through its effect on biomass and associated components. We hypothesized that CC diversity in the rotation will bring about an increase in the total biomass production, and that forces of synergism or antagonism will be at work when diverse CCs are grown in a sequence benefitting or bereaving the soil.

\section{Materials and Methods}

Field experiments were conducted from 2015 to 2017 near East Troy WI, (42.7488232, 88.4432654), representing two rotational cycles. The certified organic site has long-term organic history, transitioning in the 1980's and certified by Stellar Certification Services Inc. (Philomath, OR) since 2004. The soil type is a forest 
derived Fox silt loam (Fine-loamy, mixed, mesic Typic Hapludalfs). Soil was sampled to a depth of $15 \mathrm{~cm}$ prior to planting and analyzed for routine fertility by the University of Wisconsin Soil Test Laboratory using standard procedures: organic matter by loss of weight on ignition, $\mathrm{P}$ and $\mathrm{K}$ (Bray 1). Results are reported in Table 1.

Table 1. Experimental dates and conditions

\begin{tabular}{|c|c|c|}
\hline & Cycle 1 & Cycle 2 \\
\hline Variable/ Date & $2015-16$ & $2016-17$ \\
\hline \multicolumn{3}{|l|}{ Initial Soil Test Levels } \\
\hline $\mathrm{pH}$ & 6.9 & 7.0 \\
\hline $\mathrm{OM}\left(\mathrm{g} \mathrm{kg}^{-1}\right)$ & 2.8 & 3.6 \\
\hline Phosphorus ( $\mathrm{mg} \mathrm{kg}^{-1}$ ) & 68 & 119 \\
\hline Potassium (mg kg$\left.{ }^{-1}\right)$ & 102 & 255 \\
\hline Planting date & 4-Aug & 10-Aug \\
\hline Cover AGB Sampling & 27-Oct & 24-Oct \\
\hline Roll-crimp & 28-Oct & 25-Oct \\
\hline Rye planting & 28-Oct & 25-Oct \\
\hline Rye AGB sampling & 3-Jun & 8-Jun \\
\hline \multicolumn{3}{|l|}{ Precipitation $(\mathrm{mm})^{\dagger}$} \\
\hline Aug. (92) & 147 & 85 \\
\hline Sept. (79) & 160 & 31 \\
\hline Oct. (61) & 17 & 10 \\
\hline Nov. & 116 & 59 \\
\hline Dec.- Feb. ${ }^{\dagger \dagger}$ & 186 & 150 \\
\hline Mar. & 88 & 79 \\
\hline Apr. (101) & 51 & 149 \\
\hline May (86)The impact of & 60 & 123 \\
\hline Total $^{\dagger \dagger}$ & 690 & 707 \\
\hline \multicolumn{3}{|c|}{ Mean Monthly Temp. $\left({ }^{\circ} \mathrm{C}\right)^{\dagger \dagger}$} \\
\hline Aug. & 19.6 & 22.2 \\
\hline Sept. & 19.3 & 18.9 \\
\hline Oct. & 10.9 & 11.9 \\
\hline Nov. & 5.2 & 6.3 \\
\hline Dec- Feb. & -2.2 & -3.1 \\
\hline Mar. & 3.6 & 2.1 \\
\hline Apr. & 7.4 & 10.2 \\
\hline May & 12.9 & 12.7 \\
\hline
\end{tabular}

$\dagger$ Values in parentheses are 15-year average monthly precipitation.

Data not available for March and November at this site.

"Data from the Wisconsin State Climatology Office.

†'December - February not included in total.

Ten species (Table 2) of CCs were seeded following seed bed preparation which consisted of field cultivation. Legumes were inoculated with the appropriate peat-based strain of Rhizobium just before planting. Cover crops were planted in $19 \mathrm{~cm}$ rows using an $\mathrm{H}$ and $\mathrm{N}$ (Colwich KS) 10-row plot drill at nominal depths (0.64 to $2.54 \mathrm{~cm}$ ) based on seed size. They were allowed to grow without further management and terminated in early October by roll-crimping (I and J Manufacturing, Gordonville PA). Aboveground biomass yield was estimated by hand sampling plants at ground level from 3 rows, equivalent to $1.82 \mathrm{~m}$ of total row. Samples were dried to a constant weight at $60^{\circ} \mathrm{C}$ and ground to pass a $0.5 \mathrm{~mm}$ screen (Wiley \#4, Arthur Thomas Co., Philadelphia, PA). Samples were analyzed for $\mathrm{N}$ and $\mathrm{C}$ content by dry combustion using a Flash EA $1112 \mathrm{CN}$ Automatic Elemental Analyzer (ThermoFinnigan, Milan Italy).

Winter rye (c.v. Hancock) was no-till established following roll-crimping using the same equipment and allowed to grow to anthesis the following spring. Aboveground biomass and tissue $\mathrm{N}$ and $\mathrm{C}$ were determined using the same method as for the primary CC. 
Table 2. Aboveground biomass dry matter yield and associated components in a cover crop sequence (2015-16)

\begin{tabular}{|c|c|c|c|c|c|c|c|c|c|c|c|c|}
\hline \multirow{3}{*}{ Cover crop } & \multicolumn{3}{|c|}{$\mathrm{DM}$} & \multicolumn{3}{|c|}{$\mathrm{N}$} & \multicolumn{3}{|c|}{$\mathrm{C}$} & \multicolumn{3}{|c|}{$\mathrm{CO}_{2} \mathrm{Eq}$} \\
\hline & Cover & Rye & Total & Cover & Rye & Total & Cover & Rye & Total & Cover & Rye & Total \\
\hline & \multicolumn{3}{|c|}{$\mathrm{Mg} \mathrm{ha}^{-1}$} & \multicolumn{3}{|c|}{$-\mathrm{kg} \mathrm{ha}^{-1}-$} & \multicolumn{6}{|c|}{$\mathrm{Mg} \mathrm{ha}^{-1} \longrightarrow$} \\
\hline & & & & & & & Cycle I & & & & & \\
\hline Barley & 3.40 & 6.99 & 10.39 & 86.1 & 68.2 & 154.3 & 1.43 & 3.14 & 4.57 & 5.29 & 11.45 & 16.73 \\
\hline Buckwheat & 3.79 & 7.26 & 11.04 & 79.5 & 58.5 & 138.0 & 1.50 & 3.20 & 4.70 & 5.47 & 11.78 & 17.25 \\
\hline C. vetch & 2.46 & 8.60 & 11.07 & 99.2 & 81.5 & 180.8 & 1.10 & 3.83 & 4.93 & 3.96 & 14.00 & 17.96 \\
\hline Cowpea & 3.63 & 7.37 & 11.00 & 104.5 & 59.5 & 164.0 & 1.52 & 3.27 & 4.79 & 5.58 & 12.01 & 17.58 \\
\hline W. pea & 3.52 & 9.41 & 12.92 & 136.8 & 85.8 & 222.5 & 1.57 & 4.21 & 5.78 & 5.76 & 15.43 & 21.19 \\
\hline Phacelia & 3.76 & 9.52 & 13.28 & 125.1 & 76.9 & 202.0 & 1.48 & 4.23 & 5.71 & 5.40 & 15.52 & 20.92 \\
\hline Berseem clover & 0.76 & 6.34 & 7.10 & 22.5 & 43.2 & 65.7 & 0.31 & 2.80 & 3.11 & 1.16 & 10.26 & 11.42 \\
\hline Oat & 3.38 & 7.01 & 10.39 & 88.4 & 74.7 & 163.1 & 1.43 & 3.11 & 4.55 & 5.29 & 11.38 & 16.67 \\
\hline Radish & 3.25 & 10.71 & 13.96 & 103.6 & 107.3 & 210.9 & 1.23 & 4.79 & 6.03 & 4.52 & 17.58 & 22.11 \\
\hline Sunn hemp & 3.49 & 8.92 & 12.41 & 88.5 & 76.4 & 164.9 & 1.52 & 3.96 & 5.49 & 5.56 & 14.54 & 20.09 \\
\hline No cover & & 7.17 & 7.17 & & 53.6 & 53.6 & & 3.18 & 3.18 & & 11.65 & 11.65 \\
\hline Mean & 3.14 & 8.11 & 11.25 & 93.4 & 71.3 & 164.7 & 1.30 & 3.61 & 4.91 & 4.79 & 13.24 & 18.03 \\
\hline $1 \mathrm{sd}(0.05)$ & 0.54 & 0.91 & 0.89 & 25.7 & 20.8 & 27.3 & 0.21 & 0.41 & 0.39 & 0.79 & 1.50 & 1.42 \\
\hline$p>f$ & 0.0006 & 0.0020 & $<0.0001$ & $<0.0001$ & 0.0004 & $<0.0001$ & 0.0004 & 0.0018 & $<0.0001$ & 0.0004 & 0.0018 & $<0.0001$ \\
\hline $\mathrm{cv}(\%)$ & 26.4 & 17.4 & 12.6 & 21.3 & 22.6 & 13.6 & 25.2 & 17.5 & 12.5 & 25.4 & 17.6 & 12.5 \\
\hline \multicolumn{13}{|l|}{ Contrasts $(p>f)$} \\
\hline \multicolumn{12}{|l|}{ Means: } & \\
\hline Monocot & & 7.00 & & & 71.46 & & & 3.12 & & & 11.41 & \\
\hline Dicot & & 8.51 & & & 73.64 & & & 3.79 & & & 13.89 & \\
\hline \multicolumn{12}{|c|}{ Means: } & \\
\hline Legume & & 8.13 & & & 69.28 & & & 3.62 & & & 13.25 & \\
\hline $\begin{array}{l}\text { Nonlegume } \\
* \text { Dicots only }\end{array}$ & & 9.16 & & & 80.90 & & & 4.08 & & & 14.96 & \\
\hline
\end{tabular}

Table 3. Aboveground biomass dry matter yield and associated components in a cover crop sequence (2015-16)

\begin{tabular}{|c|c|c|c|c|c|c|c|c|c|c|c|c|}
\hline \multirow[b]{2}{*}{ Cover crop } & \multicolumn{3}{|c|}{ DM } & \multicolumn{3}{|c|}{$\mathrm{N}$} & \multicolumn{3}{|c|}{$\mathrm{C}$} & \multicolumn{3}{|c|}{$\mathrm{CO}_{2} \mathrm{Eq}$} \\
\hline & Cover & Rye & Total & Cover & Rye & Total & Cover & Rye & Total & Cover & Rye & Total \\
\hline & \multicolumn{2}{|c|}{$-\mathrm{Mg} \mathrm{ha}^{-1}$} & & \multicolumn{2}{|c|}{$\mathrm{Mg} \mathrm{ha}^{-1}-$} & & \multicolumn{2}{|c|}{$-\mathrm{Mg} \mathrm{ha}^{-1}$} & & \multicolumn{2}{|c|}{$\mathrm{Mg} \mathrm{ha}^{-1}$} & \\
\hline & & & & & & & \multicolumn{3}{|c|}{ Cycle II } & & & \\
\hline Barley & 6.47 & 4.55 & 11.02 & 163.7 & 41.9 & 205.6 & 2.69 & 2.04 & 4.73 & 9.86 & 7.48 & 17.34 \\
\hline Buckwheat & 2.89 & 5.87 & 8.76 & 46.8 & 49.2 & 96.0 & 1.19 & 2.62 & 3.81 & 4.35 & 9.63 & 13.98 \\
\hline C. vetch & 1.77 & 5.71 & 7.48 & 61.5 & 41.4 & 102.9 & 0.74 & 2.58 & 3.32 & 2.71 & 9.43 & 12.14 \\
\hline Cowpea & 1.23 & 4.64 & 5.87 & 28.2 & 35.2 & 63.4 & 0.49 & 2.08 & 2.58 & 1.84 & 7.64 & 9.48 \\
\hline W. pea & 1.72 & 5.71 & 7.44 & 62.2 & 48.7 & 110.9 & 0.72 & 2.58 & 3.29 & 2.64 & 9.43 & 12.07 \\
\hline Phacelia & 1.77 & 7.44 & 9.21 & 76.4 & 64.8 & 141.2 & 0.63 & 3.32 & 3.94 & 2.33 & 12.12 & 14.45 \\
\hline Berseem clover & 0.16 & 7.28 & 7.44 & 4.9 & 63.5 & 68.4 & 0.07 & 3.25 & 3.32 & 0.22 & 11.89 & 12.12 \\
\hline Oat & 6.63 & 5.67 & 12.30 & 176.2 & 56.6 & 232.7 & 2.76 & 2.55 & 5.31 & 10.06 & 9.32 & 19.38 \\
\hline Radish & 4.30 & 10.57 & 14.87 & 160.8 & 96.1 & 256.9 & 1.59 & 4.73 & 6.32 & 5.87 & 17.27 & 23.14 \\
\hline Sunn hemp & 2.89 & 6.83 & 9.72 & 67.8 & 55.0 & 122.8 & 1.05 & 3.05 & 4.10 & 3.90 & 11.18 & 15.08 \\
\hline No cover & & 8.31 & 8.31 & & 71.1 & 71.1 & & 3.72 & 3.72 & & 13.60 & 13.60 \\
\hline Mean & 2.98 & 6.61 & 9.59 & 84.9 & 56.7 & 141.6 & 1.19 & 2.96 & 4.05 & 4.37 & 10.82 & 15.19 \\
\hline lsd (0.05) & 0.55 & 0.78 & 1.11 & 44.5 & 18.8 & 50.0 & 0.26 & 0.35 & 0.49 & 0.95 & 1.29 & 1.79 \\
\hline$p>f$ & $<0.0001$ & $<0.0001$ & $<0.0001$ & $<0.0001$ & $<0.0001$ & $<0.0001$ & $<0.0001$ & $<0.0001$ & $<0.0001$ & $<0.0001$ & $<0.0001$ & $<0.0001$ \\
\hline $\mathrm{cv}(\%)$ & 28.6 & 18.4 & 18.5 & 40.5 & 25.7 & 29.0 & 33.6 & 18.6 & 18.7 & 33.6 & 18.5 & 18.8 \\
\hline Contrasts $(p>f)$ & $<0.0001$ & $<0.0001$ & $<0.0001$ & & & & & & & & & \\
\hline $\begin{array}{l}\text { Monocot vs. dicot } \\
\text { Means: }\end{array}$ & & 0.0017 & & & 0.2010 & & & 0.0022 & & & 0.0021 & \\
\hline Monocot & & 5.11 & & & 49.22 & & & 2.30 & & & 8.40 & \\
\hline Dicot & & 6.76 & & & 56.74 & & & 3.02 & & & 11.07 & \\
\hline $\begin{array}{l}\text { Legume vs. } \\
\text { nonlegume* }\end{array}$ & & 0.0002 & & & 0.0004 & & & 0.0002 & & & 0.0002 & \\
\hline Means: & & & & & & & & & & & & \\
\hline Legume & & 6.03 & & & 48.76 & & & 2.71 & & & 9.91 & \\
\hline $\begin{array}{l}\text { Nonlegume } \\
* \text { Dicots only }\end{array}$ & & 7.96 & & & 70.04 & & & 3.55 & & & 13.01 & \\
\hline
\end{tabular}

Cumulative CC AGB yield was determined by adding yield from the primary CC with rye. A control treatment, 
rye alone (no previous cover) was used to determine synergistic and antagonistic effects of previous cover on rye. Sequentially seeded rye yield was compared to the control to determine if yield was enhanced or reduced, enhanced yield defined as synergy, reduced yield as antagonism.

The experimental design was a randomized complete block with four replicates. Final plot size was 1.98 x 5.17 $\mathrm{m}$. Data were subject to analysis of variance procedures, Proc ANOVA (SAS Inc, Cary, NC) and means separated with a protected LDS at the 0.05 level of probability. For rye yield (Phase II), contrasts (Proc GLM) were used to determine the influence of previous crop grouping: "monocot vs. dicot" and within dicots, "legume vs. nonlegume".

\subsection{Weather Data}

Daily precipitation was measured on-site for the periods August through November and March through May. Since annual measurements are only routinely taken from April through October long-term means are not available for November and March at this site. Overwinter precipitation data, December through March as well as monthly temperature data were recorded at a National Weather Service Reporting Station and obtained through the Wisconsin State Climatology Office website (http:/www.aos.wisc.edu/ sco/climhistory/acis_stn_meta_wi_index.htm, verified 25 Jan. 2019). This reporting station is located within $19.3 \mathrm{~km}$ from the experimental site. Growing degree models for rye growth are unavailable so data are presented as mean monthly temperature [(daily maximum - daily minimum) / 2]. This data is shown in Table 1.

\section{Results and Discussion}

Weather parameters observed during the two cropping cycles are reported in Table 1. Both cycles received similar amounts of precipitation, though varied in its distribution. The fall of 2016 had lower rainfall (69 mm) compared to $2015(133 \mathrm{~mm})$. This seems to have played a role in the AGB yield of the CCs, more so as it interfered with the growth of winter rye in 2016. The mean monthly temperature was slightly higher during 2016-17 season as compared to 2015-16. The influence of weather and date of sowing on the CC biomass yields recorded in the Midwest has previously been discussed by the same authors (Stute \& Shekinah, 2019; Balkom et al., 2011).

\subsection{Biomass Yield}

Above ground biomass yield and associated components recorded for the CC sequences are reported in Tables 2 and 3. The treatment $x$ year interaction was highly significant for all variables so data is presented by cycle (I \& II). When CC AGB was determined at termination, the CCs were at different stages of crop growth as they are diverse in nature, monocot vs dicot, legume vs non-legume. The AGB yield of the CCs was significantly affected by sequence, both as a system total and when winter rye was considered solely.

The two cropping cycles (2015-16 and 2016-17) differed significantly in the AGB yields. The performance of winter rye, which was the greatest contributor to system total during both years of study, was reduced in 2016-17 cycle as was the AGB yield of the first CC. Although both years received almost equal precipitation during the season (690 and $707 \mathrm{~mm}$ in 2015-16 and 2016-17, respectively), this yield reduction was mainly caused by the variation in fall rainfall as discussed earlier. Twenty - sixteen recorded only $51 \%$ of the precipitation received in 2015 during the months of October and November. This might have interfered with germination and development of winter rye leading to the reduction in the AGB yield, and the associated components. We surmise that a good distribution of rainfall during these months is critical for germination and establishment of winter rye (October and November) and could result in higher biomass production that is advantageous to the system. Blanco - Canqui et al. (2012) have also stressed on the importance of precipitation on yields and opined that the impact of CCs on subsequent crop yields depends on precipitation, CC species, amount of biomass return, tillage management and length of CC management.

During Cycle I, the highest AGB yield of rye was achieved following dicots compared to monocots. A similar significant effect was observed in Cycle II. The CC sequence of radish- winter rye $\left(13.96 \mathrm{Mg} \mathrm{ha}^{-1}\right)$ had the highest AGB yield followed by phacelia - winter rye $\left(13.28 \mathrm{Mg} \mathrm{ha}^{-1}\right)$, and the two were not significantly different in Cycle I. The highest contribution to the system total was from winter rye in both sequences, with AGB yield of rye highly significant following radish $\left(10.71 \mathrm{Mg} \mathrm{ha}^{-1}\right)$ but being on par following phacelia, winter pea or sunn hemp. Such high biomass yields from forage radish and winter rye have been previously recorded by Hodgdon et al. (2016) in three out of four years of their New England study. Though rye biomass yield was not significantly different following winter pea or sunn hemp, the total biomass yield of those sequences were significantly greater (AGB yields of 12.92 and $12.41 \mathrm{Mg} \mathrm{ha}^{-1}$ respectively) than CC sequences of buckwheat, 
chickling vetch and cowpea followed by winter rye. In all the CC sequences tested, the highest contributor was winter rye. Table 2 shows the individual contribution of the cover crop to the system total AGB yields. The first $\mathrm{CC}$ in sequence, seeded in August and roll- crimped in October, yielded between 2.5 and $3.8 \mathrm{Mg} \mathrm{ha}^{-1}$ during the first cycle. The lowest yield contribution to the system total was from berseem clover which yielded $0.76 \mathrm{Mg}$ $\mathrm{ha}^{-1}$. Together with winter rye $\left(6.34 \mathrm{Mg} \mathrm{ha}^{-1}\right)$ this sequence yielded $7.10 \mathrm{Mg} \mathrm{ha}^{-1}$, which is lower than winter rye alone $\left(7.17 \mathrm{Mg} \mathrm{ha}^{-1}\right)$. Cover crop sequences of barley or oats followed by winter rye performed moderately in terms of total AGB yield from the system.

A similar trend was seen in Cycle II. Radish followed by winter rye recorded the significantly highest AGB yields $\left(14.87 \mathrm{Mg} \mathrm{ha}^{-1}\right)$ in this cycle. The contribution of radish to the system total increased slightly $(5.6 \%)$ while the biomass yield from winter rye remained almost the same, despite a drier fall season. Winter rye alone (control) yielded $8.31 \mathrm{Mg} \mathrm{ha}^{-1}$, which was slightly higher or on par than when grown following phacelia, buckwheat, chickling vetch, winter pea, berseem clover or cowpea. The crop sequence of barley-winter rye, and oat - winter rye produced significantly higher AGB yields (11.02 and $12.30 \mathrm{Mg} \mathrm{ha}^{-1}$ ) compared to winter rye alone. The contribution of the first CC to the sequence total AGB yield reduced during Cycle II except in the case of barley, oat and radish. This, we mainly attribute to the reduced rainfall in 2016 (which is only $37.7 \%$ of August + September precipitation of 2015) which might have impacted the moisture availability for growth. Similarly, the winter rye biomass yield reduced in Cycle II as it received only $51 \%$ of the October + November precipitation of 2015 affecting germination and establishment of winter rye.

\subsection{Synergy or Antagonism in Cover Crop Sequence?}

There are two possible sources of allelochemicals in the case of crop residues; the compounds can be released directly from crop litter or they can be produced by microorganisms that use plant residues as a substrate (Kruidhof, 2008 as reviewed in Murell et al., 2017). Regardless of the year, we observed that when the AGB yield of oat, barley and berseem clover increased, there was a reduction in the sequential winter rye biomass yield. The percentage contribution of winter rye biomass to system total was $56 \%$ following oat and 53\% when following barley. In sequential seeding with berseem clover, rye contributed $94 \%$ to the system total. Though it might seem to be a major contributor to the total it is mainly due to the negligible yield of berseem clover, but the biomass yield of rye decreased when that of berseem clover increased. We hypothesize that the increased biomass yields of oat, barley and berseem clover left as residues in the soil might have an antagonistic effect on the germinating/growing winter rye, thereby reducing yields. The inclusive definition for allelopathy recognizes that compounds are involved in the defense against multiple biological threats, including competition by other plants, herbivores and disease (Macias et al., 2007). A clearer understanding of such genotype x environmental interactions is required to better manage cover crop systems. This was not the case with other CCs where the AGB yield of the CCs in sequence increased or decreased in tandem. This could be attributed to the prevailing weather conditions and reduction in the amount of moisture available for growth due to reduced precipitation.

On the other hand, winter rye following radish was observed to have the highest AGB yield during both cycles. In sequential cover cropping, the biomass yield of radish increased in Cycle II. Radish is a $\mathrm{N}$ scavenging cover crop (Finney et al., 2016) whose residues decompose rapidly (Ruark et al., 2018) which might have increased N availability to winter rye. However, the phenomenon of yield reduction in winter rye recorded with the increase in the biomass yield of the first CC (oat, barley and berseem clover) does not seem to operate in this sequence. Rather, the AGB yield of winter rye was maintained at the same higher level. We presume that synergistic effects of radish biomass are in operation here enabling a better performance of winter rye. The allelopathic effect of brassicaceae on weeds have been documented in the green house though not at the field level by Haramoto \& Gallandt (2005). However, this is an interesting twist to the effect of brassica wherein radish as a CC shows synergy enabling the growth of winter rye. These are preliminary but interesting observations/ results that need further study and documentation.

The relative yield of winter rye by year is presented in Figure 1. The dividing line represents the control (rye alone) and clearly represents the departure of winter rye biomass yield following other covers. The decline in the relative rye yield following oat, barley and beseem clover seems to suggest the negative effect (antagonism) these CCs had on its growth and biomass production. 


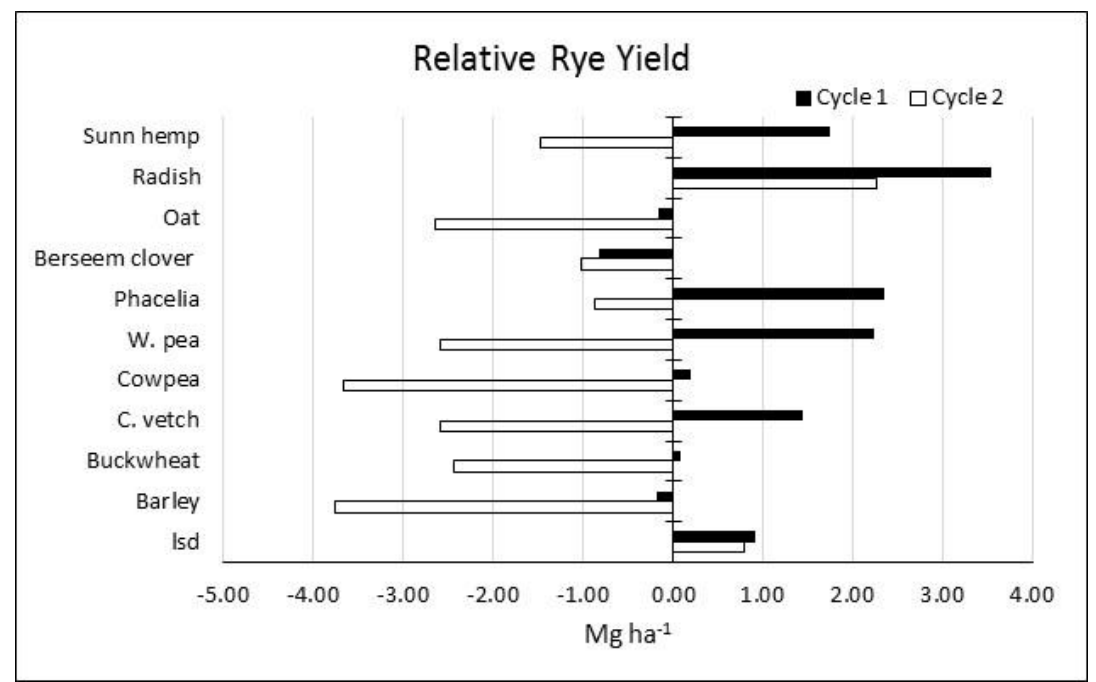

Figure 1. Relative AGB yield of rye following previous cover crops compared to rye alone

\subsection{Nitrogen and Carbon Content}

Rye can be an important component in whole farm nutrient management planning and nutrient cycling. It grows actively, takes up nutrients during late fall and early spring when significant infiltration and leaching occur (Stute et al., 2007). Potential reduction of $\mathrm{NO}_{3}-\mathrm{N}$ loss between growth cycles of annual crops with a rye $\mathrm{CC}$ was reported to average about 31\% in Midwest corn and soybean production (Iowa State University, 2014). The N and $\mathrm{C}$ content added to the soil from the cover crop sequence was mainly due to the added biomass, as both are components of dry matter. The $\mathrm{N}$ content added varied depending upon the cover crop sequence adopted. The contrast data showed that rye following dicots and legumes accumulated more $\mathrm{N}$ than when following monocots or non-legumes in Cycle II while this contrast was insignificant in Cycle I. Higher and significant $\mathrm{N}$ addition was recorded with winter pea - rye $\left(222.5 \mathrm{~kg} \mathrm{ha}^{-1}\right)$ and radish - rye $\left(210.9 \mathrm{~kg} \mathrm{ha}^{-1}\right)$ sequence in Cycle I and radish rye $\left(256.9 \mathrm{~kg} \mathrm{ha}^{-1}\right)$ and oat - rye $\left(232.7 \mathrm{~kg} \mathrm{ha}^{-1}\right)$ sequence in Cycle II. However, a variation in the contribution to the total was observed depending on the CC. On average, rye accumulated $71.3 \mathrm{~kg} \mathrm{ha}^{-1}$ of N in Cycle I and 56.1 $\mathrm{kg} \mathrm{ha}^{-1}$ in Cycle II which otherwise could have been lost through leaching or denitrification (Appelgate et al., 2017). However, Pantoja et al. (2015) have documented an $\mathrm{N}$ accumulation of only $21 \mathrm{~kg} \mathrm{ha}^{-1}$ in Iowa with winter rye. The $\mathrm{C}$ added also followed a similar trend, with just the radish-winter rye sequence being significantly higher than any other crop sequence in Cycle II.

Amongst the ten CC species tested, legumes (chickling vetch, winter pea, phacelia, cowpea) accumulated significantly higher $\mathrm{N}$ compared to cereal/grasses except berseem clover. The variation with berseem clover occurred since it produced low AGB yields in both cycles $\left(0.76\right.$ and $0.16 \mathrm{Mg} \mathrm{ha}^{-1}$ and added 22.5 and $4.9 \mathrm{~kg}$ $\mathrm{ha}^{-1}$ of $\mathrm{N}$, respectively in Cycle I and II). Legumes, by a natural process, fix atmospheric $\mathrm{N}$ in the soil and have increased $\mathrm{N}$ content compared to cereals. When the biomass produced is almost similar between legumes and cereals, as is the case in Cycle I, the legumes top the cereals in its contribution to the $\mathrm{N}$ content pool. Summer legume CCs can provide an effective protective cover to soil and supply significant amounts of $\mathrm{N}$ to subsequent crops (Schomberg et al., 2007).

In Cycle II, this changed however, and the highest $\mathrm{N}$ accumulation was with cereals, oat, barley (176.2 and 163.7 $\left.\mathrm{kg} \mathrm{ha}^{-1}\right)$ and brassica, radish $\left(160.8 \mathrm{~kg} \mathrm{ha}^{-1}\right)$. Increased biomass produced by these CCs negated the advantage of the legumes $\mathrm{N}$ fixation potential. Radish followed by winter rye seems to be the successful crop sequence to be adopted for highest addition of $\mathrm{N}$ and $\mathrm{C}$ to the soil. The synergy between these two species grown in sequence was the main reason for the increased $\mathrm{N}$ and $\mathrm{C}$ addition. The lowest $\mathrm{N}$ accumulation was in the control treatment (rye alone) in both cycles. The antagonism operating between oat, barley and winter rye might have attributed to the slight reduction in the $\mathrm{N}$ added, and we mainly attribute this to the reduction in the biomass of winter rye when following oat or barley. The other crop sequences performed moderately in terms of added $\mathrm{N}$.

The lowest $\mathrm{C}$ added was when rye followed monocots in both cycles. Even though legumes did not make a difference to the $\mathrm{C}$ added in Cycle I, in Cycle II, the $\mathrm{C}$ addition was more when rye followed legumes. Residues of the cover crop sequence berseem clover - rye in Cycle I and cowpea - rye in Cycle II added significantly high 
amounts of $\mathrm{C}$ to the soil. Winter rye, by virtue of producing higher AGB yield added more $\mathrm{C}$ to the soil and was the major contributor of $\mathrm{C}$ to the cover crop sequence total. The summer cover crop has a higher $\mathrm{N}$ content and lower $\mathrm{C}$ and is secondary to winter rye in contribution to system $\mathrm{C}$ totals. Soil organic $\mathrm{C}$ directly influences soil biological, chemical and physical properties, which affect soil productivity and environmental quality (Ruis \& Blanco- Canqui., 2017).

\subsection{C:N Ratio}

The C:N ratio of the different $\mathrm{CC}$ species residues grown in late summer is shown in Table 4. It serves as a good indicator of $\mathrm{N}$ mineralization and residue retention (Quemada \& Cabrera, 1995). A higher $\mathrm{N}$ content in the biomass means that the $\mathrm{C}: \mathrm{N}$ is lower. Otherwise more $\mathrm{C}$ is added to the soil and it takes longer for the residues to decompose. When combined over two years, lower C:N were recorded with chickling vetch (11.6), winter pea (11.6), radish (11.1) and phacelia (10.2). Similar results of lower C:N with Brassicaceae and vetch sole crops has been reported by Appelgate et al. (2017). Biomass from these crops rapidly decompose to add nutrients to the soil, which might aid the growth of the following rye. The total AGB yield recorded was highest with radish or phacelia followed by winter rye in Cycle I and radish - winter rye in Cycle II demonstrating this. It brings about the synergistic effect of radish in enabling the growth of winter rye in both cycles. Cover crop residues that have a higher C:N remain on the soil and decompose slowly and release accumulated $\mathrm{N}$ more slowly to the following crop (Quemada \& Cabrera, 1995). This may also explain the lower rye biomass yield following oats, barley and berseem clover (C:N of 16.2, 16.8 and 13.3 respectively, when combined over both cycles).

Table 4. C:N ratio of the cover crops in sequence

\begin{tabular}{lllll}
\hline Tmt \# & Species & Combined $^{*}$ & Cycle I & Cycle II \\
\hline 1 & Barley & 16.8 & 16.8 & 16.8 \\
2 & Buckwheat & 23.2 & 19.1 & 27.3 \\
3 & C. vetch & 11.6 & 10.9 & 12.2 \\
4 & Cowpea & 16.2 & 14.7 & 17.7 \\
5 & W. pea & 11.6 & 11.5 & 11.7 \\
6 & Phacelia & 10.2 & 11.9 & 8.5 \\
7 & Berseem clover & 13.3 & 14.3 & 12.3 \\
8 & Oat & 16.2 & 16.3 & 16 \\
9 & Radish & 11.1 & 11.6 & 10.6 \\
10 & Sunn hemp & 15.8 & 17.1 & 14.4 \\
& lsd (0.05) & 3.2 & 2.3 & 6.1 \\
& Mean & 14.6 & 14.4 & 14.7 \\
& cv $(\%)$ & 21.9 & 10.8 & 28.7 \\
& p $<\mathrm{f}$ & $<0.0001$ & $<0.0001$ & $<0.0001$ \\
\hline & & & & \\
\hline
\end{tabular}

*tmt x year 0.0341

Buckwheat had significantly highest $\mathrm{C}: \mathrm{N}$ of all the treatments. Residues with $\mathrm{C}: \mathrm{N}$ of less than $16: 1$ is unlikely to cause $\mathrm{N}$ immobilization (Weinert et al., 2002 as reviewed in Appelgate et al., 2017). He also documented that $\mathrm{CCs}$ that are winter killed release $\mathrm{N}$ faster than those that over winter.

\section{$3.5 \mathrm{CO}_{2}$ Equivalent}

The CE mirrored the effects of cover crop sequence on carbon since it is a calculated quantity from biomass $\mathrm{C}$, as the vast majority of $\mathrm{C}$ in plant tissue comes from the atmosphere through photosynthesis (Stute, MFAI Website). Ruis et al. (2018) reported that the $\mathrm{CC}$ effect on $\mathrm{CO}_{2}$ emissions or $\mathrm{CE}$ are linked to biomass production and is limited to the growing period only. Stute (MFAI Website) opined that this carbon capture is not permanent but a strategy to take $\mathrm{CO}_{2}$ "out of play" in the short term, some released back as $\mathrm{CO}_{2}$ as residues decompose while the more stable form staying in the soil for years. The contrast data showed that the CE was higher when rye followed dicots or legumes, similar to that of $\mathrm{C}$ added.

The radish - winter rye crop sequence had the highest CE yield in Cycle I although the other sequences containing winter pea, phacelia or sunn hemp were not significantly different. Cycle II followed the trend of carbon content with radish- winter rye recording significantly highest CE $\left(23.14 \mathrm{tha}^{-1}\right)$. How much of it is of the stable form and how much is released back warrants further study. Kim et al (2010) and Haque et al. (2015) have reported that increased $\mathrm{CO}_{2}$ emissions under CCs happen only when they increased SOC concentration. In this study, we present this data with the intent of building the literature database for use in future $\mathrm{C}$ crediting systems. 


\section{Conclusions}

Growing CCs after harvest of the short season summer crop followed by a winter CC in sequence helps achieve ground cover that could prevent the loss of soil through erosion, and nitrogen through leaching, especially during the late fall/ early spring. It may also have added benefits of better nutrient cycling, improved infiltration and weed control through the addition of residues. Different species: barley, buckwheat, chickling vetch, cowpea, winter pea, phacelia, berseem clover, oat, sunn hemp and radish when tested in a sequence where rye followed each of those in winter, showed that radish - winter rye sequence was the best in terms of addition of high amounts of biomass, $\mathrm{C}, \mathrm{N}$ and other associated benefits. It also showed synergistic interactions by way of improved performance of winter rye in sequence, followed by the phacelia - winter rye sequence. Oats, barley or berseem clover seemed to show antagonism towards winter rye in sequence bringing about a reduction in the biomass yield of winter rye but balancing out on the $\mathrm{N}$ and $\mathrm{C}$ addition as well as the $\mathrm{CE}$ due to the higher biomass they produced. Whenever the yield of the three cool season CCs namely oats, barley and berseem clover increased, there was a reduction in the rye yield. The other $\mathrm{CC}$ sequences performed intermediately which was more of a response to the prevailing weather conditions. This investigation points to the prevalence of synergy and antagonism operating between cover crops in sequence which needs to be explored in detail in future research, along with changes in relation to temperature, precipitation and other growth conditions.

\section{Acknowledgements}

This work was partially funded by a USDA ARS Cooperative Agreement (58-5090-7-072). The authors gratefully acknowledge the assistance of David Andrews, Phil Klamm, Rylan McGuigan and Rachel Stute with field work and sample processing. Mention of commercial products is for clarification only and does not imply endorsement by the authors or the Michael Fields Agricultural Institute.

\section{References}

Altieri, M. (1999). The ecological role of biodiversity in agroecosystems. Agric. Ecosyst. Environ., 74, 19-31. https://doi.org/10.1016/S0167-8809(99)00028-6

Appelgate, S. R., Lenssen, A. W., Wiedenhoeft, M. H., \& Kaspar, T. C. (2017). Cover crop options and mixes for upper Midwest corn-soybean systems. Agron. J., 109(3), 968-984. https://doi.org/10.2134/agronj2016.08.0453

Ashford, D. L., \& Reeves, D. W. (2003). Use of a mechanical roller-crimper as an alternative kill method for cover crops. Am. J. Alternative Agric., 18, 37-45. https://doi.org/10.1079/AJAA2003037

Balkcom, K. S., Massey, J. M., Mosjidis, J. A., Price, A. J., \& Enloe, S. F. (2011). Planting Date and Seeding Rate Effects on Sunn Hemp Biomass and Nitrogen Production for a Winter Cover Crop. International Journal of Agronomy, 2011, 8. https://doi.org/10.1155/2011/237510

Blanco-Canqui, H., Classen, M. M., \& Presley, R. D. (2012). Summer cover crops fix nitrogen, increase crop yield and improve soil-crop relationships. Agron. J., 140(1), 137-147. https://doi.org/10.2134/agronj2011.0240

Finney, D. M., White, C. M., \& Kaye, J. P. (2016). Biomass production and carbon/nitrogen ratio influence ecosystem services from cover crop mixtures. Agron. J., 108, 39-52. https://doi.org/10.2134/agronj15.0182

Haque, M. M., Kim, S. Y., Ali, M. A., \& Kim, P. J. (2015). Contribution of greenhouse gas emissions during cropping and fallow seasons on total global warming potential in mono-rice paddy soils. Plant and Soil, 387, 251-264. https://doi.org/10.1007/s11104-014-2287-2

Haramoto, E. R., \& Gallandt, E. R. (2004). Brassica cover cropping for weed management: A review. Renew. Agric. Food Syst., 19(4), 187-198. https://doi.org/10.1079/RAFS200490

Haramoto, E. R., \& Gallandt, E. R. (2005). Brassica cover cropping: 1. Effects on weed and crop establishment. Weed Sci., 53(5), 695-701. https://doi.org/10.1614/WS-04-162R.1

Hodgdon, E. A., Warren, N. D., Smith, R. G., \& Sideman, R. G. (2016). In-Season and Carry-Over Effects of Cover Crops on Productivity and Weed Suppression. Agron. J., 108, 1624-1635. https://doi.org/10.2134/agronj2015.0419

Iowa State University. (2014). Reducing nutrient loss: Science shows what works. Publ. SP 435. Iowa State Univ. Ext. and Outreach, Ames. Retrieved from https://store.extension.iastate.edu/product/Reducing-Nutrient-Loss-Science-Shows-What-Works

Johnson, T. J., Kaspar, T. C., Kohler, K. A., Corak S. J., \& Logsdon, S. D. (1998). Oat and rye over-seeded into 
soybean as fall cover crops in the upper Midwest. J. Soil Water Conserv., 53, 276-279.

Kim, S. Y., Gutierrez, J., \& Kim, P. J. (2012). Considering winter cover crop selection as green manure to control methane emission during rice cultivation in paddy soil. Agriculture, Ecosystems and Environment, 161, 130-136. https://doi.org/10.1016/j.agee.2012.07.026

Kruidhof, H. M. (2008). Cover crop-based ecological weed management: Exploration and optimization. Ph.D. thesis. Wageningen Univ., Wageningen, The Netherlands.

Kuo, S., Sainju, U. M., \& Jellum, E. J. (1997a). Winter cover crop effects on soil organic carbon and carbohydrate. Soil Sci. Soc. Am. J., 61, 145-152.

https://doi.org/10.2136/sssaj1997.03615995006100010022x

Kuo, S., Sainju, U. M., \& Jellum, E. J. (1997b). Winter cover cropping influence on nitrogen in soil. Soil Sci. Soc. Am. J., 61, 1392-1399. https://doi.org/10.2136/sssaj1997.03615995006100050016x

Macias, F. A., Molinillo, J. M. G., Varela, R. M., \& Galindo, J. C. G. (2007). Allelopathy-A natural alternative for weed control. Pest Manage. Sci., 63, 327-348. https://doi.org/10.1002/ps.1342

Mirsky, S., Curran, W. S., Mortensen, D. A., Ryan, M. R., \& Shumway, D. (2009). Control of cereal rye with a roller/crimper as influenced by cover crop phenology. Agron. J., 101, 1589-1596.

https://doi.org/10.2134/agronj2009.0130

Moore, E. B., Wiedenhoeft, M. H., Kaspar, T. C., \& Cambardella, C. A. (2014). Rye Cover Crop Effects on Soil Quality in No-Till Corn Silage-Soybean Cropping Systems. Soil Sci. Soc. Am. J., 78, 968-976. https://doi.org/10.2136/sssaj2013.09.0401

Murell, E. G., Schipanski, M. E., Finney, D. M., Hunter, M. C., Burgess, M., LaChance, J. C., Baraibar, B., White, C. M., Mortensen, D. A., \& Kaye, J. P. (2017). Achieving diverse cover crop mixtures: Effects of planting date and seeding rate. Agron. J., 109, 259-271. https://doi.org/10.2134/agronj2016.03.0174

Pantoja, J. L., Woli, K. P., Sawyer, J. E., \& Barker, D. W. (2015). Corn nitrogen fertilization requirement and corn-soybean productivity with a rye cover crop. Soil Sci. Soc. Am. J., 79, 1482-1495. https://doi.org/10.2136/sssaj2015.02.0084

Quemada, M., \& Cabrera, M. L. (1995). Carbon and nitrogen mineralized from leaves and stems of four cover crops. Soil Sci. Soc. Am. J., 59, 471-477. https://doi.org/10.2136/sssaj1995.03615995005900020029x

Raimbault, B. A., Vyn, T. J., \& Tollenaar, M. (1990). Corn Response to Rye Cover Crop Management and Spring Tillage Systems. Agron. J., 82, 1088-1093. https://doi.org/10.2134/agronj1990.00021962008200060012x

Reddy, K. N., Zablotowicz, R. M., Locke, M. A., \& Koger, C. H. (2003). Cover crop, tillage, and herbicide effects on weeds, soil properties, microbial populations, and soybean yield. Weed Sci., 51, 987-994. https://doi.org/10.1614/P2002-169

Ruark, M. D., Chawner, M. M., Ballweg, M. J., Proost, R. T., Arriaga, F. J., \& Stute, J. K. (2018). Does Cover Crop Radish Supply Nitrogen to Corn?. Agron. J., 110, 1513-1522. https://doi.org/10.2134/agronj2017.06.0352

Ruis, S. J., \& Blanco-Canqui, H. (2017). Cover Crops Could Offset Crop Residue Removal Effects on Soil Carbon and Other Properties: A Review. Agron. J., 109, 1785-1805. https://doi.org/10.2134/agronj2016.12.0735

Ruis, S., Blanco, K., Wortmann, C., \& Jin, V. (2018). Cover crop and CO2 emissions. Retrieved from https://cropwatch.unl.edu/2018/cover-crop-and-co2-emissions_(accessed 10 Dec. 2018).

Schomberg, H. H., Martini, N. L., Diaz-Perez, J. C., Phatak, S. C., Balkcom, K. S., \& Bhardwaj, H. L. (2007). Potential for Using Sunn Hemp as a Source of Biomass and Nitrogen for the Piedmont and Coastal Plain Regions of the Southeastern USA. Agron. J., 99, 1448-1457. https://doi.org/10.2134/agronj2006.0294

Shekinah, D. E., \& Stute, J. K. (2018). Sunn hemp: A legume cover crop with potential for the Midwest?. Sustainable Agriculture Research, 7(4), 63-69. https://doi.org/10.5539/sar.v7n4p63

Singer, J. W. (2008). Corn Belt assessment of cover crop management and preferences. Agron. J., 100, 1670-1672. https://doi.org/10.2134/agronj2008.0151

Snapp, S. S., Swinton, S. M., Labarta, R., Mutch, D., Black, J. R., Leep, R., Nyiraneza, J., \& O’Neil, K. (2005). Evaluating cover crops for benefits, costs and performance within cropping system niches. Agron. J., 97, 322-332. 
Stute, J. K. (2018). MFAI Website. Retrieved from http://michaelfields.org/cover-crops-co2-and-carbon-credits

Stute J. K., \& Esther, S. D. (2019). Planting date and biculture affect sunn hemp productivity in the upper-Midwest. Sust. Ag. Res., 8(2), 26-35. https://doi.org/10.5539/sar.v8n2p26

Stute, J. K., Shelley, K.., Mueller, D., \& Wood, T. (2007). Planting winter rye after corn silage: managing for forage. University of Wisconsin Nutrient and Pest Management Program publication 1-0907-5C. Retrieved from https://ipcm.wisc.edu/download/pubsNM/Rye_090507_final.pdf (verified 5th Feb. 2019).

Teasdale, J. R. (1996). Contribution of cover crops to weed management in sustainable agricultural systems. $J$. Prod. Agric., 9, 475-479. https://doi.org/10.2134/jpa1996.0475

Teasdale, J. R., Brandsaeter, L. O., Calegari, A., \& Skora, N. F. (2007). Cover crops and weed management. In: M. K. Upadhyaya and R. E. Blackshaw, (Eds.), Non-chemical weed management. CAB Int., Wallingford, UK. https://doi.org/10.1079/9781845932909.0049

Tilman, D., Lehman, C. L., \& Thomson, K. T. (1997). Plant diversity and ecosystem productivity: Theoretical considerations. Natl. Acad. Sci. USA, 94, 1857-1861. https://doi.org/10.1073/pnas.94.5.1857

Weinert, T. L., Pan, W. L., Moneymaker, W. R., Santo, G. S., \& Stevens, R. G. (2002). Nitrogen recycling by nonleguminous winter cover crops to reduce leaching in potato rotations. Agron. J., 94, 365-372. https://doi.org/10.2134/agronj2002.0365

Wortman, S. E., Francis, C. A., \& Lindquist, J. L. (2012a). Cover crop mixtures for the western Corn Belt: Opportunities for increased productivity and stability. Agron. J., 104, 699-705.

https://doi.org/10.2134/agronj2011.0422

Wortman, S. E., Francis, C. A., Bernards, M. L., Drijber, R. A., \& Lindquist, J. L. (2012b). Optimizing Cover Crop Benefits with Diverse Mixtures and an Alternative Termination Method. Agron. J., 104, 1425-1435. https://doi.org/10.2134/agronj2012.0185

\section{Copyrights}

Copyright for this article is retained by the author(s), with first publication rights granted to the journal.

This is an open-access article distributed under the terms and conditions of the Creative Commons Attribution license (http://creativecommons.org/licenses/by/3.0/). 